\title{
Perbandingan Kadar Seng Plasma pada Diare Akut Gizi Baik dan Gizi Kurang Anak Usia 6 bulan-2 tahun
}

Riwi Dwi Surjani, Ina Rosalina, Azhali MS

Bagian Ilmu Kesehatan Anak Fakultas Kedokteran Universitas Padjadjaran/Rumah Sakit Dr. Hasan Sadikin Bandung

Latar belakang. Diare menjadi salah satu penyebab utama morbiditas dan mortalitas pada anak di bawah usia 5 tahun, dengan insidens tertinggi pada usia 6 bulan-2 tahun. Selama diare berlangsung terjadi penurunan kadar seng plasma. Kondisi ini makin diperberat jika sebelumnya telah terjadi deplesi seng plasma pada anak dengan status gizi kurang.

Tujuan. Membandingkan kadar seng plasma pada anak diare akut gizi baik dan gizi kurang usia 6 bulan-2 tahun.

Metode. Comparative study dengan rancangan penelitian cross sectional yang dilaksanakan di RS Hasan Sadikin, RS Ujung Berung, dan RS Cibabat sejak Oktober sampai Desember 2007. Setiap subjek penelitian diambil sampel darah untuk diperiksa kadar seng plasma, status gizi diperiksa dengan skor Z. Kadar seng plasma $<84,5 \mu \mathrm{g} / \mathrm{dL}$ dikategorikan rendah dan $\geq 84,5 \mu \mathrm{g} / \mathrm{dL}$ normal. Analisis statistik dihitung dengan menggunakan uji t untuk mengetahui perbedaan kadar seng plasma rata-rata antara anak diare akut gizi baik dan kurang serta uji $x^{2}$ untuk mengetahui perbedaan antara kadar seng plasma normal dan rendah pada anak diare akut gizi baik dan kurang.

Hasil. Dari 60 subjek penelitian terdapat 30 anak gizi kurang dan 30 anak gizi baik yang menderita diare akut. Terdapat 24 anak gizi kurang dan tujuh anak gizi baik yang memiliki kadar seng plasma di bawah nilai normal. Kadar seng plasma rata-rata pada anak diare akut gizi baik adalah $(104,38 \pm 19,31) \mu \mathrm{g} / \mathrm{dL}$ dan $(69,20 \pm 15,77) \mu \mathrm{g} / \mathrm{dL}$ pada anak diare akut gizi kurang $(p=0,000)$. Hasil uji $x^{2}$ menunjukkan kadar seng plasma anak diare gizi kurang secara bermakna lebih rendah daripada kadar seng plasma anak diare akut gizi baik $\left(x^{2}=19,288 ; p=0,000\right)$.

Kesimpulan. Kadar seng plasma pada anak gizi kurang usia 6 bulan-2 tahun yang menderita diare akut lebih rendah dibandingkan dengan anak gizi baik. (Sari Pediatri 2008;10(3):196-200).

Kata kunci: kadar seng plasma, gizi baik, gizi kurang

Alamat Korespondensi:

Riwi Dwi Surjani, dr. SpA, Bagian Ilmu Kesehatan Anak Fakultas Kedokteran Universitas Padjadjaran/Rumah Sakit Dr. Hasan Sadikin Jl. Pasteur No. 38 Bandung 40163, Indonesia. Telp. 022-2035957. E-mail: riwi_surjani@yahoo.com.

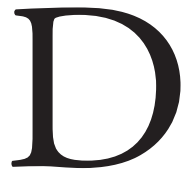

iare menjadi salah satu penyebab utama morbiditas dan mortalitas pada anak di bawah usia 5 tahun. Rata-rata setiap anak mengalami 2,6 kali episode diare per tahun 
dengan insiden tertinggi terjadi pada usia 6 bulan-2 tahun yaitu 5 episode diare per tahun. ${ }^{1} \mathrm{Di}$ Indonesia berdasarkan hasil Survei Kesehatan Rumah Tangga tahun 1980 diare merupakan penyebab kematian nomor satu pada golongan bayi (22/1.000) dan balita (6,6/1.000) Pada tahun 1985 turun menjadi penyebab kematian nomor dua pada golongan bayi (13,3/1.000) dan balita (3,7/1.000), sedangkan pada tahun 1995 merupakan penyebab kematian ke-3 pada bayi (8/1.000) dan ke-2 pada golongan balita (1/1.000). ${ }^{2}$ Menurut laporan Subdit Program Penanggulangan Diare (P2D) Dirjen P2M dan PL Departemen Kesehatan, pada balita angka kesakitan relatif stabil dari tahun 1989-1993, berkisar 1.026/1.000 balita. Namun sejak tahun 1996 cenderung meningkat menjadi 1.078 dan tahun 2000 menjadi 1.278/1.000 balita, ${ }^{2}$ sedangkan berdasarkan hasil survei tahun 2003 diare memiliki prevalensi paling tinggi pada anak usia 6 bulan-2 tahun. Hasil data Survei Kesehatan Nasional tahun 2003 menempatkan diare sebagai penyebab kematian kedua pada anak usia di bawah 5 tahun, dengan insidens puncak terjadi pada usia 6 bulan-2 tahun. ${ }^{2}$

Diare menyebabkan penurunan status seng pasien karena adanya gangguan penyerapan dan anoreksia. ${ }^{3}$ Berbagai penelitian yang dilakukan membuktikan penurunan kadar seng plasma pada pasien diare akut. Makin lama diare berlangsung, makin rendah kadar seng plasma. Demikian juga makin besar volume tinja yang keluar makin banyak terjadi kehilangan seng. ${ }^{4,5}$ The Zinc Investigator's Colaborative Group memberikan seng dalam bentuk asetat atau glukonas dengan dosis $4-5 \mathrm{mg} / \mathrm{kgbb}$ dan $20 \mathrm{mg}$ pada anak dengan diare akut, akan mengurangi lama serta beratnya diare. Penelitian lain yang memberikan $20 \mathrm{mg}$ seng elemental pada anak usia 3-24 bulan yang terserang diare akut mendapat penurunan stool output dan memperpendek masa diare. $^{6}$

Tata laksana diare telah ditandatangani sebagai kebijakan politik bersama oleh WHO dan UNICEF pada bulan Mei 2004, salah satu kebijakan tersebut adalah memberikan suplementasi seng selama 10-14 hari. ${ }^{7}$ Sejalan dengan kebijakan WHO-UNICEF tata laksana diare pada anak menempatkan nutrisi pada posisi penting, karena adanya hubungan timbal balik (bi-directional) antara malnutrisi dan infeksi (termasuk diare infeksius). Diare dapat menurunkan status nutrisi karena penurunan asupan makanan, gangguan penyerapan, peningkatan katabolisme, dan ekskresi nutrien. Sebaliknya malnutrisi merupakan predisposisi infeksi (termasuk diare infeksius) karena menurunkan fungsi imunitas dan pertahanan tubuh. Dengan demikian terapi nutrisi yang baik dapat memutuskan rantai, sehingga lingkaran antara diare dan malnutrisi akan terputus pula. ${ }^{8,9}$

Seng adalah mineral esensial yang terdapat pada hampir setiap sel. Defisiensi seng (bagian dari trace element) dapat terjadi akibat asupan dan penyerapan seng yang kurang, serta pengeluaran yang berlebihan. Kelompok yang paling rentan terhadap kondisi ini adalah anak dalam masa pertumbuhan, masa produktif, masa penyembuhan, anak dengan gangguan nutrisi, dan anak yang terserang diare. ${ }^{10}$ Menurut Prasad AS gangguan nutrisi jauh lebih banyak terdapat dalam bentuk ringan. ${ }^{10}$

Berbagai penelitian telah dilakukan untuk melihat dampak suplementasi seng terhadap kejadian diare pada anak yang diduga mengalami defisiensi seng. Semua penelitian ini menunjukkan penurunan yang bermakna terhadap insidens diare akut pada anak yang mendapat seng. ${ }^{10,11}$ Beberapa faktor lain yang mempengaruhi kadar seng seng plasma di antaranya,

- Penyakit saluran cerna termasuk diare, terjadi kehilangan seng sejalan dengan peningkatan volume tinja pasien. ${ }^{4}$

- Kurang gizi, terjadi defisiensi berbagai trace element akibat kurangnya asupan, salah satu di antara trace alement tersebut adalah seng. ${ }^{12}$

- Asupan makanan yang mengandung fitat, menyebabkan daya ikat seng berkurang. Kompleks fitat-seng ini tidak dapat diserap oleh mukosa usus. ${ }^{13,14}$

- Kelainan primer defisiensi seng, seperti pada akrodermatitis enteropatika. ${ }^{13}$

- Defisiensi seng sekunder, keadaan ini dapat terjadi pada penyakit infeksi seperti infeksi saluran napas bawah akut yang berat dan malaria. ${ }^{13,14}$

- Hipoalbuminemia, diketahui albumin mengikat seng dalam darah untuk selanjutnya digunakan oleh tubuh sesuai keperluan. ${ }^{15}$

Tujuan penelitian membandingkan kadar seng plasma antara anak diare akut gizi baik dan gizi kurang usia 6 bulan-2 tahun.

\section{Metode}

Penelitian comparative study dengan rancangan penelitian cross sectional, dilakukan di Bagian Ilmu 
Kesehatan Anak RS Hasan Sadikin, RS Ujung Berung, dan RS Cibabat sejak bulan OktoberDesember 2007. Subjek penelitian dengan kriteria inklusi (1) Pasien diare akut yang dirawat atau berobat jalan di Bagian Ilmu Kesehatan Anak RS Hasan Sadikin, RS Ujung Berung, dan RS Cibabat, (2) Usia 6 bulan-2 tahun, (3) Berstatus gizi baik dan kurang berdasarkan pemeriksaan antropometri menggunakan skor Z. Kriteria eksklusi pada penelitian ini, (1) Menderita infeksi saluran napas bawah akut, (2) Menderita malaria, (3) Secara klinis menderita defisiensi seng berat seperti alopesia dan akrodermatitis enteropatika.

Sampel darah untuk pemeriksaan kadar seng plasma diambil sebanyak $5 \mathrm{~mL}$, dimasukkan kedalam tabung lalu disentrifus. Selanjutnya diambil $1 \mathrm{~mL}$ plasma dan dimasukkan kedalam tabung khusus, untuk diukur kadar seng plasmanya dengan menggunakan metode atomic absorption spectrometry. Status gizi dihitung menggunakan skor $Z$. Anak dengan status gizi kurang memiliki skor $Z$ yaitu kurang -1 sampai dengan -2 . Kadar seng plasma dikategorikan rendah jika $<84,5 \mu \mathrm{g} / \mathrm{dL}$, dan dikategorikan normal jika $\geq 84,5 \mu \mathrm{g} / \mathrm{dL}$.

Ethical clearance didapat dari Komisi Etik Penelitian Kesehatan Fakultas Kedokteran Universitas

\section{Hasil}

Hasil penelitian didapat 60 anak usia 6 bulan-2 tahun yang menderita diare akut dengan status gizi baik dan kurang berdasarkan pemeriksaan antropometri. Dari sejumlah 60 anak terdapat 30 anak diare akut berstatus gizi baik dan sebanyak 30 anak diare akut berstatus gizi kurang.

Kelompok anak gizi baik terdapat 17 anak laki-laki dan 13 anak perempuan (Tabel 1), sedangkan pada kelompok gizi kurang terdapat 20 anak laki-laki dan 10 anak perempuan. Rata usia dari kedua kelompok penelitian 11 bulan. Hari sakit rata-rata saat bahan pemeriksaan berupa sampel darah diambil adalah hari kedua terserang diare. Pada kelompok gizi baik 25 anak terserang diare akut nondisentri dehidrasi ringan sedang dan lima anak menderita diare akut nondisentri dehidrasi berat. Pada kelompok gizi kurang terdapat 30 anak diare akut nondisentri dehidrasi ringan sedang dan tidak seorang anakpun yang menderita dehidrasi berat.

Pada Tabel 2 tertera, sejumlah 30 anak diare akut gizi kurang mempunyai kadar seng plasma rata-rata $(69,20 \pm 15,77) \mu \mathrm{g} / \mathrm{dL}$, sedangkan pada anak diare akut gizi baik mempunyai kadar seng plasma ratarata $(104,38 \pm 19,31) \mu \mathrm{g} / \mathrm{dL}$. Berdasarkan uji t didapat

Tabel 1. Karakteristik subjek penelitian

\begin{tabular}{lcc}
\hline Karakteristik & Gizi baik (n) & Gizi kurang (n) \\
\hline Subjek penelitian (anak) & 30 & 30 \\
Jenis kelamin (anak) & & \\
$\quad$ Laki-laki & 17 & 20 \\
$\quad$ Perempuan & 13 & 10 \\
Rata-rata usia (bulan) & 11 & 11 \\
Rata-rata hari sakit & 2 & 2 \\
Jumlah kasus diare akut (anak) & & \\
$\quad$ Nondisentri dehidrasi ringan sedang & 25 & 30 \\
$\quad$ Nondisentri dehidrasi berat & 5 & - \\
\hline
\end{tabular}

Padjadjaran/RS Hasan Sadikin Bandung. Pasca penelitian data diolah dengan menggunakan program SPSS versi 14.0 for Window tahun 2007 dan uji t untuk mengetahui perbedaan kadar seng plasma rata-rata antara anak diare akut gizi baik dan kurang serta uji $x^{2}$ untuk mengetahui adanya perbedaan antara kadar seng plasma rendah dan norma pada anak diare akut gizi baik dan kurang.
Tabel 2. Perbandingan kadar seng plasma rata-rata antara anak diare akut gizi baik dan gizi kurang

\begin{tabular}{lcc}
\hline Status gizi & $\mathrm{n}$ & $\begin{array}{c}\text { kadar seng plasma }(\mu \mathrm{g} / \mathrm{dL}) \\
(\text { rerata } \pm \text { SB) }\end{array}$ \\
\hline Kurang & 30 & $69,20 \pm 15,77$ \\
Baik & 30 & $104,38 \pm 19,31$ \\
\hline
\end{tabular}

Nilai $p=0,000$ 
perbedaan yang bermakna antara kadar seng plasma rata-rata dari dua kelompok $(p=0,000)$. Kadar seng plasma rata-rata anak diare akut gizi kurang lebih rendah dibandingkan anak diare akut gizi baik.

Kelompok anak diare akut gizi baik terdapat tujuh anak $(11,7 \%)$ mempunyai kadar seng plasma rendah dan 23 anak (76,7\%) mempunyai kadar seng plasma normal. Pada anak diare akut gizi kurang didapat 24 anak (40\%) mempunyai kadar seng plasma rendah dan sisanya enam anak (10\%) mempunyai kadar seng plasma normal. Kadar seng plasma pada anak diare akut gizi kurang lebih rendah bermakna dibandingkan anak diare akut gizi baik $\left(x^{2}=19,288 ; p=0,000\right)$ (Tabel $3)$. kadar seng plasma rendah $(<60 \mu \mathrm{g} / \mathrm{dL})$. Penelitian di New Delhi ini tidak memperhatikan status gizi dan hasil tersebut adalah data awal sebelum anak tersebut dikelompokkan dalam tiga kelompok perlakuan yang mendapatkan berbagai bentuk suplementasi seng hingga akhir penelitian. ${ }^{18}$ Penelitian lain dilakukan pada anak diare akut usia 9 bulan-6 tahun dengan malnutrisi sedang-berat menunjukkan kadar seng plasma yang rendah $(<72 \mu \mathrm{g} / \mathrm{dL})$. Kadar seng plasma ini cenderung menjadi normal kembali setelah dua minggu fase penyembuhan. ${ }^{19}$ Meskipun tidak memeriksa kadar seng plasma pada anak diare akut dengan berbagai status gizi, terdapat penelitian yang menunjukkan anak dengan kadar seng plasma yang

Tabel 3. Kadar seng plasma pada anak diare akut gizi baik dan gizi kurang

\begin{tabular}{lcccc}
\hline Karakteristik & \multicolumn{2}{c}{ Gizi Baik } & \multicolumn{2}{c}{ Gizi Kurang } \\
\cline { 2 - 5 } & $\mathrm{n}$ & $\%$ & $\mathrm{n}$ & $\%$ \\
\hline Kadar seng plasma & & & & \\
Rendah $(<84,5 \mu \mathrm{g} / \mathrm{dL})$ & 7 & 11,7 & 24 & 40 \\
Normal $(\geq 84,5 \mu \mathrm{g} / \mathrm{dL})$ & 23 & 38,3 & 6 & 10 \\
\hline$\chi 2=19,288$ dengan nilai $\mathrm{p}=0,000$ & & &
\end{tabular}

\section{Pembahasan}

Sejumlah 30 anak pasien diare akut berstatus gizi kurang, 24 anak di antaranya mempunyai kadar seng plasma $<84,5 \mu \mathrm{g} / \mathrm{dL}$ dan tujuh anak gizi baik (keseluruhan 51,7\%) memiliki kadar seng plasma di bawah normal (cut-offpoint $<84,5 \mu \mathrm{g} / \mathrm{dL}$ ). Cut-offpoint kadar seng plasma pada penelitian lain juga bervariasi. RS Hoesin Palembang memakai batas kadar seng plasma $<70 \mu \mathrm{g} / \mathrm{dL}$ pada bayi yang dirawat dengan diare akut. Hasilnya didapat $60 \%$ anak dengan kadar seng plasma $<70 \mu \mathrm{g} / \mathrm{dL}$. Salah satu penelitian pada balita pengunjung RS Cipto Mangunkusumo dan Pusat Pengembangan Gizi Bogor mendapatkan bahwa kadar seng plasma pada balita gizi buruk $(41,03 \pm 13,7) \mu \mathrm{g} / \mathrm{dL}$, pada balita gizi kurang $(56 \pm 15,56) \mu \mathrm{g} / \mathrm{dL}$, dan pada balita gizi baik $(73,75 \pm 10,32) \mu \mathrm{g} / \mathrm{dL} .{ }^{16}$

Selain itu terdapat penelitian yang dilakukan pada 130 balita di kabupaten Magelang Jawa Tengah didapat rata-rata kadar seng plasma $(43,3 \pm 30,4) \mu \mathrm{g} /$ dL. Penelitian tersebut tidak dilakukan pada balita sehat. ${ }^{17}$ Salah satu penelitian yang dilakukan di New Delhi pada sejumlah 1.219 anak diare akut usia 6-35 bulan menunjukkan $33,7 \%$ subjek penelitian memiliki rendah memiliki risiko sebesar $47 \%$ lebih tinggi terserang diare akut dibandingkan dengan kadar seng plasma normal. ${ }^{18}$

Pada penelitian kami, dari kelompok anak dengan status gizi kurang didapat lima orang anak menderita diare akut dehidrasi berat $(15,67 \%)$ dengan kadar seng plasma seluruhnya di bawah nilai normal $(<84,5 \mu \mathrm{g})$ dL). Dibandingkan dengan penelitian yang dilakukan oleh Robert, ${ }^{20}$ pemberian suplementasi seng pada anak diare akut dengan berbagai derajat hidrasi secara statistik tidak menunjukkan perbedaan bermakna terhadap lamanya diare. Kedua penelitian tidak dapat dibandingkan, karena pada penelitian kami tidak memberi perlakuan (pemberian suplementasi seng) pada anak diare akut dehidrasi ringan-sedang dan berat. Penelitian lain yang dilakukan di Nagpur India terhadap 200 anak usia 6-59 bulan yang terserang diare akut didapatkan hasil dari kelompok uji 2,9\% anak dehidrasi berat, 11,7\% anak dehidrasi ringan sedang, dan 85,2\% anak tanpa dehidrasi. Pada kelompok plasebo (tidak mendapat suplementasi seng) 3\% anak dehidrasi berat, 14,2\% anak dehidrasi ringansedang, dan $82,6 \%$ anak tanpa dehidrasi. Penelitian di Nagpur ini menyatakan faktor terpenting yang 
berperan terhadap lamanya diare tergantung pada derajat berat diare ketika pasien diikutsertakan dalam penelitian, dan bukan bergantung pada pemberian suplementasi seng. Penelitian di Nagpur ini bertujuan melihat kadar seng plasma saat diare berlangsung dan menyatakan bahwa derajat hidrasi berpengaruh terhadap durasi diare. ${ }^{20}$

Melihat berbagai penelitian di atas, maka hasil penelitian ini memberikan informasi dan mendukung hasil-hasil penelitian lain yang telah dilakukan sebelumnya. Kesimpulan dari penelitian kami bahwa kadar seng plasma pada anak diare akut usia 6 bulan-2 tahun dengan status gizi kurang lebih rendah dibandingkan dengan anak diare akut gizi baik. Maka temuan kami menunjang tata laksana seng pada kasus diare akut sesuai anjuran WHO

\section{Daftar Pustaka}

1. Black RE, Bryce J, Boschi-Pinto C, Shibuya K. WHO estimates of the causes of death in children. Lancet 2005;365:1147-52.

2. Departemen Kesehatan dan Kesejahteraan Sosial Republik Indonesia, Ditjen Pemberantasan Penyakit Menular dan Penyehatan Lingkungan (PPM-L). Laporan hasil survei angka kesakitan diare dan perilaku ibu dalam tatalaksana diare balita. Jakarta: PPM-L; 1999.

3. Lee RG, Rains TM, Tovar-Palacio, Beverly JL, Shay NF. Zinc deficiency increases hypothalamic neuropeptide $\mathrm{Y}$ and neuropeptide $\mathrm{Y}$ mRNA levels and does not block neuropeptide Y-induced feeding in rats. J Nutr 1998;128:1218-23.

4. Castillo-Duran C, Vial P, Uauy R. Trace mineral balance during acute diarrhea in infants. J Pediatric 1988;113:452-7.

5. Prasad AS. Discovery of human zinc deficiency of zinc. Dalam: Tomita H (penyunting). Trace elements in clinical medicine. Tokyo: Springer-Verlag; 1999. h. 3-11.

6. Roy SK, Behrens RH, Haider R, Akramuzaman SM, Mahalanabis D, Wahed MA, et al. Impact of seng suplementation on intestinal permeability in Bangladesh children with acute diarrhea and persitent diarrhea syndrome. J Ped Gastroenterol Nutr 1992;15:289-96.

7. World Health Organisation-UNICEF. WHO/UNICEF joint statement: clinical management of acute diarrhea. New York: The United Nations Children's Fund/World Health Organization; 2004.
8. Kosek M, Bern C, Guerrant RL. The global burden of diarrhoea diseases as estimated from studies published between 1992 and 2000. Bull WHO. 2003;81:197-204.

9. Brown KH, Sara E, Peerson JM. The importance of zinc in human nutrition and estimation of the global prevalence of zinc deficiency. Food Nutrit Bull 2001;22:31.

10. Prasad AS. Discovery of human zinc deficiency of zinc. Dalam: Tomita $\mathrm{H}$, penyunting. Trace elements in clinical medicine. Tokyo: Springer-Verlag; 1999. h. 3-11.

11. Castillo-Duran C, Vial P, Uauy R. Trace mineral balance during acute diarrhea in infants. J Pediatric 1988;113:452-7.

12. Krebs FN. Trace elements. Dalam: Walker AW, Watkins JB, Duggan C (penyunting). Nutrition in pediatrics basic science and clinical applications. London: Hamilton; 2003. h. 86-110.

13. Sandstrom B. Diagnosis of zinc deficiency and excess in individuals and populations. Food Nutrit Bull. 2001;22:32.

14. Shankar AH, Prasad AS. Zinc and immune function: the biological basis of altered resistence to infection. Am J Clin Nutr 1998;68:447-63.

15. Molla AM, Molla A, Sarker SA, Rahaman MM. Food intake during and after recovery from diarrhea in children. Dalam: Lincoln C. Chen and Nevin S. Scrimshaw, penyunting. Diarrhea and malnutrition: interactions, mechanisms and interventions. New York; Plenum Press, 1983. h.113-23.

16. Sayogo S. Defisiensi zinc pada anak usia 2-15 tahun di kelurahan Utan Kayu Utara. Maj Kes Masy Indon. 1993;1:4-8.

17. Koesnadi D. Hubungan kadar zinc plasma dengan status gizi balita. Majalah Ilmu Kedokteran Universitas Gajah Mada. 1995;27:81-8.

18. Rajiv Bahl. Efficacy of zinc-fortified oral rehydration solution in 6 to 35 months old children with acute diarrhea. J Pediatr 2002;141:677-82.

19. Sarker SA, Rahaman MM, Ali A, S Hossain. Prolonged depression of serum zinc concentration in children following post-measless diarrhea. Hum Nutr Clin Nutr 1985;39:411-7.

20. Robert RE. Zinc deficiency, infectious diseases and mortality in the developing countries. J Nutr 2003; 133:1485-89.

21. Patel B, Dhandee L, Manwar R. Therapeutic evaluation of zinc and cooper supplementation in acute diarrhea in children: double blind randomized trial. Indian Pediatrics 2005;42:433-42. 